\section{Cutaneous adverse drug reaction in Human \\ Immunodeficiency virus patient associated with antiviral therapy: $A$ retrospective study}

\author{
Vidyani Adiningtyas, ${ }^{1}$ \\ Cita Rosita Sigit Prakoeswa, ${ }^{1}$ \\ Erwin Astha Triyono ${ }^{2}$ \\ ${ }^{1}$ Department of Dermatology and \\ Venereology, Faculty of Medicine, \\ Universitas Airlangga,/Dr. Soetomo \\ General Hospital, Surabaya; \\ ${ }^{2}$ Department of Internal Medicine, \\ Faculty of Medicine, Airlangga \\ University/Dr. Soetomo General \\ Hospital, Surabaya, Indonesia
}

\begin{abstract}
Drug hypersensitivity reactions specifically cutaenous adverse drug reaction (CADR) occur at higher rate in human immunodeficiency virus (HIV)positive patients than general population and cause significant morbidity, in early era of antiretroviral therapy (ART), the incidence of skin rashes can reach $50 \%$ in HIV patients taking HIV medications. The purpose of this study is to evaluate the pattern of CADR in HIV patients associated with ART. A retrospective study took data from medical record CADR in HIV patients associated with ART at HIV ward, Dr. Soetomo General Hospital Surabaya, since January 2013 until December 2015. During the period of three years, there were 20 CADR patients in at HIV ward, Dr. Soetomo General Hospital Surabaya. The most common patient was male, with the highest age group of 25-44 years old, and the most clinical feature found were maculopapular rash, and Steven Johnson Syndrome (SJS). The most common antiviral therapy were nevirapine. The number of CADR in HIV patient associated with ART cases increased. The most clinical feature were maculopapular rash followed by SJS, only few cases of toxic epidermal necrolysis.
\end{abstract}

\section{Introduction}

Human immunodeficiency virus (HIV) is a lymphotropic human retrovirus, which is predominantly transmitted through sexual contact. Other important means of transmission include exposure to infected blood (including needles shared by injecting drug users and "skin popping") and transmission from an infected mother to her infant during pregnancy, delivery, or breastfeeding. The introduction of antiretroviral therapy (ART) has markedly altered the life expectancy and quality of life for many of the 33.4 million individuals worldwide infected with HIV. Cutaneous disorders occur in nearly every patient during the course of HIV disease, either as a result of acquired immunodeficiency or from treatment. ${ }^{1}$

Cutaneous adverse drug reaction (CADR) is the most common manifestation of drug hypersensitivity. Patients can present exanthema without systemic symptoms or drug hypersensitivity syndromes typically manifesting as an erythematous, maculopapular confluent rash with constitutional features (fever, rigors, myalgias, and arthralgias) in the presence or absence of internal organ involvement (hepatitis, pneumonitis, myocarditis, pericarditis, and nephritis). Stevens Johnson syndrome (SJS) or toxic epidermal necrolysis (TEN) develop in less than $0.5 \%$ of patients. A study by Coopman et al. which included 684 HIV-infected patients from The Harvard Community Health Plan's records showed that CADR accounted for $8.2 \%$ dermatologic diagnoses of HIV patients. The most common CADR is morbilliform rash. Others were urticaria, erythema multiforme, vasculitis, exfoliative dermatitis, and photodermatitis. Most of CADR in HIV patients are induced by cotrimoxazole. Antiretroviral medications have also been associated with CADR, ranging from mild exanthemas to lifethreatening reactions, such as SJS or TEN. ${ }^{2}$

The incidence of adverse cutaneous drug eruptions is estimated to be as much as 100 times more common in individuals with untreated HIV disease compared to that in the general population, and may become more frequent with advancing immunodeficiency. ${ }^{1-4}$ Although there have been case reports of nearly all antiretroviral drugs and drug hypersensitivity, the antiretroviral drugs most commonly associated with such syndromes include abacavir, a nucleoside analogue, the nonnucleoside reverse transcriptase inhibitors (NNRTIs; nevirapine, efavirenz, delavirdine, TMC-125, TMC-278), fosamprenavir, an HIV protease inhibitor and enfuvirtide (T-20), an HIV fusion inhibitor. ${ }^{4}$

Factors that have been associated with increased risk of drug eruptions include female gender, CD4+ T cell count $<200 / \mu \mathrm{L}$, CD $8+\mathrm{T}$ cell count $>460 / \mu \mathrm{L}$, and a history of having had drug eruptions in the past. ${ }^{1}$

Diagnosis and management of drug hypersensitivity in HIV-infected patients is
Correspondence: Vidyani Adiningtyas, Department of Dermatology and Venereology, Faculty of Medicine, Universitas Airlangga/ Dr. Soetomo General Hospital, J1. Prof. Dr. Moestopo no. 47, Surabaya, Indonesia.

Te.:+6281.938.435.181

E-mail: vadiningtyas@gmail.com

Key words: human immunodeficiency virus, retrovirus, antiretroviral therapy, cutaneous adverse drug reaction, immunodeficiency.

Contributions: The authors contributed equally.

Conflict of interest: The authors have nothing to disclose.

Received for publication: 1 February 2019. Accepted for publication: 13 February 2019.

This work is licensed under a Creative Commons Attribution-NonCommercial 4.0 International License (CC BY-NC 4.0).

(C) Copyright V. Adiningtyas et al., 2019 Licensee PAGEPress, Italy

Dermatology Reports 2019; 11(s1):8059 doi:10.4081/dr.2019.8059

difficult because multiple medication regimens are used to treat patients. It is very challenging to determine which drugs cause the reactions. ${ }^{2}$

\section{Materials and Methods}

We conducted a descriptive retrospective study using medical record of cutaneous adverse drug reaction in HIV patient associated with antiviral therapy since January until December 2015 at HIV ward in Dr. Soetomo General Hospital Surabaya. Participating practices provides information on patient demographics and characteristics (e.g age, sex, trigger factors), and medical diagnoses which are directly generated by the medical record.

\section{Results}

The observed patients encompassed 20 CADR associated with ART cases, of which $65 \%$ were male. The vast majority $(85 \%)$ of patients were at the range of 25-44 years old, Among patients identified having CADR, 65\% were identified as having maculopapular rash, 20\% were diagnosed as Steven Johnson Syndrome, 5\% were erythroderma and also TEN, with the onset maculopapular rash within 1-7 days (45\%) and 7-14 days (20\%), Steven Johnson Syndrome within 1-7 days (25\%) and erythroderma also TEN were each within 1- 
7days (5\%) The most associated ART was nevirapine $45 \%$. Distribution of subjects' characteristics can be seen in Table 1 .

\section{Discussion}

In this study, the prevelance of CADR in HIV patients associated with ART were $20(62.5 \%)$ of the total 32 CADR patients who are hospitalized in HIV Ward Dr. Soetomo General Hospital in January 2013

Table 1. Characterics of subjects with CADR in HIV patient associated with ART in HIV ward Dr. Soetomo General Hospital Surabaya since 2013-2015.

\begin{tabular}{|c|c|}
\hline Characterictics & Total (\%) \\
\hline CADR & 32 \\
\hline CADR associated with ART & $20(62.5)$ \\
\hline $\begin{array}{l}\text { Age category n (\%) } \\
\quad<1 \\
1-4 \\
5-14 \\
15-24 \\
25-44 \\
45-64 \\
>65\end{array}$ & $\begin{array}{l}0(0) \\
0(0) \\
0(0) \\
1(5) \\
17(85) \\
2(10) \\
0(0)\end{array}$ \\
\hline $\begin{array}{l}\text { Diagnosis } \\
\text { Maculopapular rash } \\
\text { Steven Johnson Syndrome (SJS) } \\
\text { Erythrodermi e.c drug eruption } \\
\text { Toxic Epidermal Necrolysis (TEN) }\end{array}$ & $\begin{array}{l}13(65) \\
5(20) \\
1(5) \\
1(5)\end{array}$ \\
\hline $\begin{array}{l}\text { Onset } \\
\text { Maculopapular rash } \\
\text { 1-7 days } \\
\text { 7-14 days }\end{array}$ & $\begin{array}{l}9(45) \\
4(20)\end{array}$ \\
\hline $\begin{array}{l}\text { Steven Johnson Syndrome (SJS) } \\
\text { 1-7 days }\end{array}$ & $5(25)$ \\
\hline $\begin{array}{l}\text { Eritrodermi e.c drug eruption } \\
\text { 1-7 days }\end{array}$ & $1(5)$ \\
\hline $\begin{array}{l}\text { Toxic Epidermal Necrolysis (TEN) } \\
\text { 1-7 days }\end{array}$ & $1(5)$ \\
\hline $\begin{array}{l}\text { Antiretroviral therapy } \\
\text { Maculopapular rash } \\
\text { Nevirapine } \\
\text { Zidovudine+Lamivudine } \\
\text { Efavirenz } \\
\text { Tenovofir } \\
\text { Lamivudine }\end{array}$ & $\begin{array}{c}9(45) \\
10(50) \\
4(10) \\
3(15) \\
3(15)\end{array}$ \\
\hline $\begin{array}{l}\text { Steven Johnson Syndrome } \\
\text { Nevirapine } \\
\text { Zidovudine+Lamivudine } \\
\text { Lamivudin } \\
\text { Tenofovir }\end{array}$ & $\begin{array}{l}5(25) \\
4(20) \\
1(5) \\
1(5)\end{array}$ \\
\hline $\begin{array}{l}\text { Erythrodermi e.c drug eruption } \\
\text { Nevirapine } \\
\text { Zidovudine+Lamivudine }\end{array}$ & $\begin{array}{l}1(5) \\
1(5)\end{array}$ \\
\hline $\begin{array}{l}\text { Toxic epidermal necrolysis } \\
\text { Efavirenz } \\
\text { Lamivudine } \\
\text { Tenofovir }\end{array}$ & $\begin{array}{l}1(5) \\
1(5) \\
1(5)\end{array}$ \\
\hline
\end{tabular}

-December 2015. The total HIV /AIDS patient were 2168 patients. A study by Coopman et al. which included 684 HIVinfected patients from The Harvard Community Health Plan's records showed that CADR accounted for $8.2 \%$ dermatologic diagnoses of HIV patients. ${ }^{2}$

Studies have reported to be more prevalent in middle-aged adults and female, as reported in Tatiparthi and Mamo journal, from a total of 233 HIV positive adult patients on HAART treatment, 141 were females, 211 (90.6\%) aged between 15-49 years old. ${ }^{5}$ In this retrospective study, 1 patient (5\%) aged 15-24, 17 (85\%) aged 2544 , followed by 2 patients $(10 \%)$ aged $45-$ 64.

Cutaneous drug eruptions including morbilliform rash, urticaria, hypersensitivity syndrome, SJS, and TEN are the most frequent side effects of the medication and may be seen in as many as $35 \%$ of patients. ${ }^{6}$ Morbilliform eruptions are by far the most common manifestation, accounting for about $75 \%-95 \%$ of cases. ${ }^{1}$ Based on this study, the most common diagnosis were maculopapular rash $65 \%$, followed by Steven Johnson Syndrome $20 \%$, Erythroderma caused by drug eruption and Toxic Epidermal Necrolysis each were $5 \%$.

The most common ART associated with CADR were nevirapine in each diagnosis. There were $45 \%$ cases of Maculopapular rash, $25 \%$ of SJS, and 5\% erythroderma caused by drug eruption were associated with nevirapine. Drugs are the most common cause of SJS; more than 100 different agents have been reported to cause SJS. Nevirapine is the classic example of an HIV drug associated with SJS/TEN. ${ }^{7}$ The present study found that antiretroviral drug nevirapine (NVP) was most commonly associated with CADRs in an outpatient setting. NVP was incriminated in 39 out of $69(39 / 69,56.12 \%)$ cases of MP rash and 5 out of $8(5 / 8,62.5 \%)$ cases of urticaria. All four cases of SJS, two cases of pustular rash and two cases of angioedema were attributed to NVP. NVP is the most commonly used non-nucleoside reverse transcriptase inhibitor (NNRTI) as a part of first-line ART. Besides NVP, other antiretroviral drugs namely efavirenz, zidovudine, lamivudine and atazanavir were also suspected in CADRs especially MP rash in present study. ${ }^{8}$

Because the risk of severe CADR appears to be greatest within the first several weeks of treatment, standard recommendations are to start nevirapine at a half-dose $(200 \mathrm{mg})$ for the first 2 weeks. Anto'n et al. (1999) compared this regimen to an even more gradual escalating schedule
(100 mg _ 1 week, $200 \mathrm{mg} \quad 1$ week, 300 $\mathrm{mg} \_1$ week, then full dose $400 \mathrm{~g}$ ) and found that $8.5 \%$ of 166 patients on the standard schedule had to discontinue the medication due to rash compared with $2.1 \%$ of 97 patients using a more gradual taper. Tolerance induction with graded dosing of nevirapine in conjunction with antihistamines has also been successful in two of three patients who had previously failed treatment due to non-bullous cutaneous reactions. ${ }^{6,9}$

The diagnosis and treatment of drug hypersensitivity to antivirals, as per any drugs, is still largely based on clinical assessment of the specific syndrome involved. As per other drugs the presence of mild to moderate rash without systemic symptoms, internal organ or mucosal involvement is commonly associated with many antiviral drugs. Desensitization or graded re-introduction of drug has also been used to reintroduce an antiviral where the original reaction consisted of an isolated mild to moderate skin rash. ${ }^{9,10,11}$

\section{Conclusions}

Drug hypersensitivity is common for those living with HIV and its pathophysiology is complex and multifactorial. Early recognition and withdrawal of the drug is essential particularly in those with the more severe reactions. More studies are also needed to understand the mechanisms of antiretroviral hypersensitivity so that better strategies for prevention and treatment can be defined.The importance of this is emphasized by the fact that allergic reactions with anti-HIV drugs are not restricted to the older compounds, and will thus continue to be a clinical problem.

\section{References}

1. Uihlein L, Saavedra AP, Johnson RA. Fitzpatrick's dermatology in general medicine. 8th ed. New York: The McGraw-Hill Companies; 2012. pp. 4574-5

2. Yunihastuti E, Widhani A, Karjadi TH. Drug hypersensitivity in human immunodeficiency virus-infected patient: challenging diagnosis and management. Asia Pac Allergy 2014;4:54-67. doi:10.5415/apallergy. 2014.4.1.54.

3. Chaponda M, Pirmohamed M. Hypersensitivity reactions to HIV therapy. $\mathrm{Br} \mathrm{J}$ Clin Pharmacol 2011;71:659-67.

4. Phillips E, Mallal S. Drug 
hypersensitivity in HIV. Curr Opin Allergy Clin Immunol 2007;7:324-30.

5. Tatiparthi R, Mamo Y. Prevalence of ADRs and associated factors of antiretroviral treatment on HIV positive adults at Jush. IJOPP 2015;7:8-15.

6. Svensson CK, Cowen EW, Gaspari AA. Cutaneous drug reaction. Pharmacol Rev 2000;53:357-79.

7. Borras-Blasco J, Navarro-Ruiz A, Borras C, Castera E. Adverse cutaneous reactions associated with the newest antiretroviral drugs in patients with human immunodeficiency virus infection. J Antimicrob Chemother 2008;62:879-88.

8. Pawar M, Pore S, Pradhan S, et al. Nevirapine: Most common cause of cutaneous adverse drug reactions in an outpatient department of a tertiary care hospital. J Clin Diagn Res 2015;9: FC17-20.

9. Milpied-Homsi M, Moran EM, Philips EJ. Antiviral drug allergy. Immunol
Allergy Clin North Am 2014;34:64562.

10. Davis C, Shearer W. Diagnosis and management of HIV drug hypersensitivity. J Allergy Clin Immunol 2008;121:826-32.

11. Phillips JE. Approach to Hypersensitivity syndrome associated with antiretroviral agents. PRN Notebook 2000;5:1-4. 